\title{
The Design and Application of Computer Assisted Language Learning System in Business English Writing course
}

\author{
Xi Wen Zhang ${ }^{1}$, Da Peng Wang ${ }^{2}$ \\ ${ }^{1}$ Foreign Languages' College, Beihua University, Jilin City, China \\ 2 Financial Information Center, Jilin City, China
}

\begin{abstract}
The CALL (Computer Assisted Language Learning) system is an effective method in business English writing teaching, particularly for students which are non-speaking countries. The CALLS is suited to self-learning because of the Rich scenario module design. Application results are examined by using the methods of group experiments, questionnaires, examinations and others. The CALLS is especially suited to creating a better studying atmosphere among students in the process of business English writing teaching than other methods.
\end{abstract}

\section{General instruction}

With the deepening of China's reform and opening up, the gradual improvement of the market economic system and successfully joined the WTO, the 2008 Olympic Games and other world language-which highlights the importance of English is already self-evident. Especially in recent years the talent market feedback information indicates that the sharp increase in demand for highquality whole society foreign trade personnel, where universities have graduate business English knowledge background of much foreign trade enterprises welcome. This makes the college and students are increasingly attach importance to business English courses are and learning to meet the social demand for complex English talents.

English as a compulsory course important universities, has long been seen as an important but isolated public basic courses, taught content is difficult to effectively combine with students future career, it is difficult to meet the different jobs actual needs. The Business English development and late in the development of English for a long time, so in the realization of the "service for the purpose of employment-oriented" use "of engineering combined with" training mode, to achieve culture technology, production, management and service the first line target process senior skilled personnel in the higher vocational education, with a big gap between the current situation and the training objectives. The reason, first of all is to limit classroom teachers professional background knowledge, in general, a high level of English teachers, but the lack of specific business practices; secondly, for themselves as well as teaching materials for classroom teaching content, are primarily text based materials, even if equipped with audio-visual materials are also part of the older or divorced from reality, which makes it difficult to truly feel the situation of students, it cannot effectively participate, cannot achieve interactive teaching.

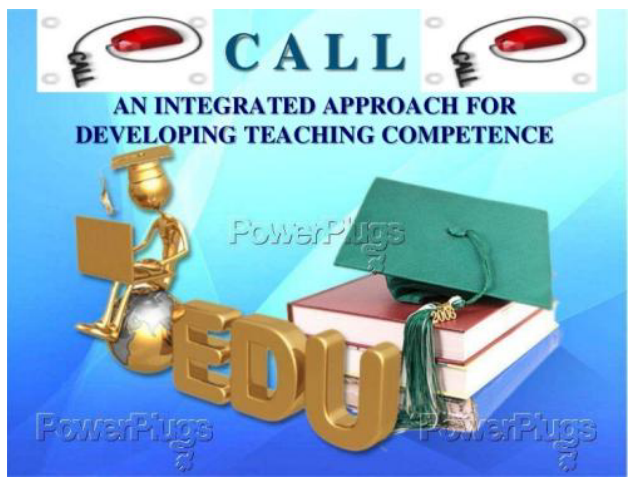

Figure 1. Computer assisted language learning system

\section{Computer-aided instructions (CAI) of manifestations}

The use of multimedia technology is computer-aided instruction (CAI) of manifestations, but also the traditional teaching of the application process and form a comprehensive and creative. Multimedia for its interactive, good visibility, broad content, interesting and other distinctive features, to the education sector has brought new changes, creating a new era of teaching methods. Many suitable for the teaching of multimedia authoring software, such as Authorware, PowerPoint, Director, Flash, etc., beautifully produced courseware for teachers to provide a guarantee, it can greatly increase students' interest in learning and teaching. Especially the 
multimedia courseware show integration, the selection of hypertext links, operational human-computer interaction, the richness of a large capacity storage, high-speed transmission of convenience, Macros communication sharing and other advantages can be achieved classroom teaching holistic, scientific, artistic and technical unity binding, for the "business English" This door requires a lot of interaction and practice course has a very important significance.

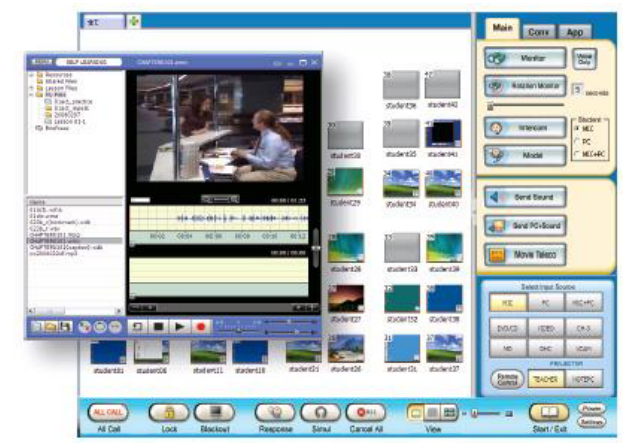

Figure 2. Classroom management software and interactive interface

\section{Application Status Multimedia Technology in Teaching}

Multimedia is accompanied by the development of computer hardware and software technology to produce and mature. It refers to the audio-visual and other graphic information conveyed in the form of synthesis. Can be summarized as understanding on the computer platform of the information carrier, including graphic images, audio, video, text, collection, processing, handling and reproduction, so that the expression of a more comprehensive information and expression.

Multimedia technology in the process of development of modern education, the first is the introduction of projection, slides, audio, video and other technologies, resulting in audio-visual education. Then with the rapid development in recent years, computer communication technology, modern education also applied computer computer-assisted instruction, that CAI (Computer-Aided Instruction) instruction. We can say that modern education is an ongoing achievement of modern science and technology applied to education practice process. Visual Education's strengths lie in its audio-visual nature. The downside is that one-way information dissemination. The CAI teaching on the contrary, interactive communication teaching information, but the lack of audio-visual teaching functions. The $1980 \mathrm{~s}$ and the emergence are the CAI Trial VTR teaching a combination of modes, an interactive audio-visual teaching (Interactive Video) prototype, which is talking about multimedia teaching herein.

Multimedia technology, through the computer using text, text, voice, music, graphics, images, animation and other media information are digitized, and integrate it in a certain interactive interface that enables a computer to interact with the ability to show different forms of media, complete Some traditional teaching methods can not be achieved easily or teaching tasks, particularly reflected in the image of the teaching and the simulation shows: the electronic lesson plans, the image of teaching, interactive process simulation, network multimedia teaching, simulation processes are all multimedia technology in teaching practical results reflect . It combines illustrations, sensual taste, lively as a whole, rich teaching in music, visual content. It can not only be teaching, counseling, self-test, consolidate, review, assessment integration, but also in the students learning ability and mobilize the enthusiasm of students, improve learning outcomes, abilities and other aspects also play a huge role.

Multimedia technology assisted teaching can make learning interactive integrated information see illustrations, audio-visual integration, especially the formation of multimedia courseware, both teaching of reading in multimedia courseware content, you can also get sound or video-related information associated with classroom teaching watch the sequence of development of things, the sequence of events in order to observe the laws and principles summarized. This new form of access to information greatly changed the traditional mode of boring single teaching method, so that learners can intuitively vividly to obtain and understand information, to produce learning and fun-loving, active and timely access to information stimulate expression Desire, which naturally form teacher-student interaction.

Multimedia technology assisted teaching enables students to integrate information see interactive illustrations, audio-visual one, you can read in the multimedia courseware teaching content, you can also hear from the classroom associated with sound information, procedures, and laws and principles viewing event. This new form of information has changed the boring single teaching mode, so that students can understand more image information, producing learning and fun-loving, active and timely access to information stimulate the expression of desire, which naturally form teacher-student interaction.

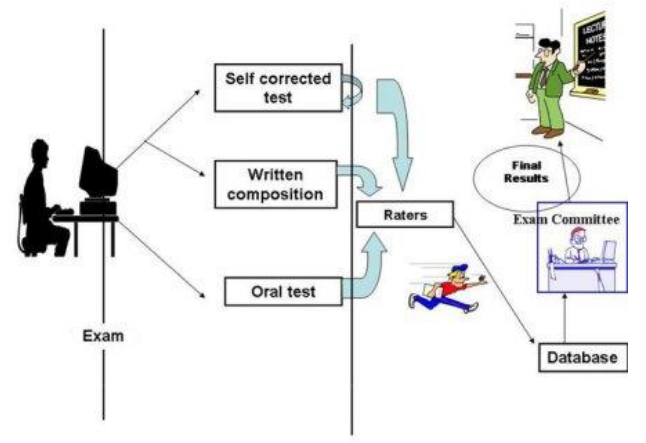

Figure 3. European association for computer assisted language learning

\section{Universities Business English Course Features}

Business English is a functional variant of English, is a special kind of use of English, it is in a particular 
situation - that is, business occasions communicative English language, so it is a manifestation of a form of communicative competence, both with business activities professional, closely related to the ordinary people use basic English. Basic English is to learn business English the premise that there is no solid foundation of knowledge and skills in English; they would not learn business English. With the economic globalization and China to accelerate the development process of internationalization, the major institutions of higher learning should be required to have a professional business English and now. As an independent professional, including Business English, international business, financial English, foreign correspondence, marketing, English, Business Writing, foreign trade practices, business negotiations, foreign trade business practical operation of other major programs have been carefully divided and were opened, achieve a professor of English as a media student business knowledge, so as to nurture both fluent in English and familiar with international business practices talent goals. But as the world labour market continues to heat up the international business demand for talent, it had just opened in the major colleges of Business English professional "Business English" course, gradually being touted in many of our universities. Colleges and universities under the principle of "employment-oriented", in order to adapt to life in the workplace language requirements for the purpose, according to the characteristics of the actual situation of their institutions and students to different modes creation of "Business English" course, teaching content related to all aspects of business activities, but tend to pay more attention to students' language skills and communication skills. Courses are fundamental purpose is to make students English language skills and business practice, and effective combination of knowledge and students' future career, to meet the actual needs of the future for the English students in different jobs.

Therefore, the required English language skills and business expertise has become a close combination of Business English Courses greatest feature. This particularity is also being decided teachers in the "Business English" Teaching should not only pay attention to the basic training of students' English language skills, but also to strengthen the training of students and business expertise. Business English because English is more focused than the average on the application, so in teaching should not follow the traditional language teaching methods to minimize the proportion of basic knowledge of the language taught, expand the proportion of training in order to train students' language proficiency for the purpose of increasing the yield Right out of the number and weight. In the course of business English teaching, teachers teaching and students' self-learning must be combined with each other, to establish and implement a studentcentered teaching self-learning mode, in order to communicate meaning for the purpose of requiring students in cognitive learning process to master professional business knowledge, to consolidate and strengthen its expertise in business practice and simulation application, and internalized cognitive learning. After learning and training, students with English as the media can really properly understood, handled and answered questions in a variety of business activities, and to establish and to maintain business ties with business partners, to improve the business communication skills. Also because of the special nature of this course, the effect evaluation criteria Business English course should be students' language communicative effectiveness and accuracy using business knowledge.

\section{Interactive Teaching Business English}

In the traditional classroom, there is a scene typical of teaching very common scenario: A teacher asked the students after school finished: "There are questions you do not understand the students please raise your hands?!" But often this time no people raised their hands. Are students really doing not have any doubt? There are several possible answers, perhaps some students did not think to mention the issue, perhaps introverted students did not dare show in front of the class of this class have not understood place, perhaps some students want to go back again after review relating to supplementary questions, perhaps there is no doubt that we indeed, it may just come across in the course of doing homework, in fact, such teachers in teaching and received no effective teaching subject - students, feedback information, and their level of understanding. Even if only a few people to ask questions, because of the relationship between classrooms forty minutes of class time, the teacher can only answer these questions, or simply left to the individual school and then answer. It can be seen, between teachers and students did not play an effective information feedback, the lack of communication between teachers and students interact.

Business English and general English comparison more difficult, mainly because the former includes not only the use of everyday language, but there are many technical terms, polite language to communicate with people, liturgical language, etc., and the need to finance, finance, e-commerce and domestic and international trade and the Anglo-American culture and other various disciplines, so the teachers and students, in the process of teaching and learning has a certain degree of difficulty, not the students lack of interest is that teachers lack teaching situations. Or, although students recognize the importance of business English, teachers also do everything possible to create the appropriate language to go with the situation, but the separation of limited hours, learning and practicing, or reach, "so that students will be in English language skills and business practices combined, and the mastery of knowledge and students' future career effectively combine to meet the actual needs of different jobs, "this goal. Center interactive teaching mode is "exchange", the classroom is the most wanted in the form of exchange, no classroom exchange, and there would be no conditions for implementation of classroom teaching. Effective classroom teaching to achieve the 
purpose of the exchange is the prerequisite. From the perspective of exchange of information, the exchange of information between teachers and students is two-way; there is a lot of exchange of information between them. Therefore, the implementation of interactive teaching method based Business English Teaching is very necessary.

\section{Interactive multimedia technologies in the sense of teaching}

Meaning for the development of multimedia technology previously described characteristics and business English courses and interactive teaching, interactive multimedia technology in teaching business English is imperative. Concrete can be summarized as the following aspects:

First, students can take the initiative to learn. Through the use of multimedia technology to enhance teaching content rich and interesting, interactive teaching model to encourage students to participate, learn to enjoy the fun by participating in cattle, and can take the initiative to identify problems, propose to ask management, or even active thinking to find solutions to problems this greatly stimulated the enthusiasm of student learning active learning.

Second, the student becomes the real subject. Interactive, multimedia courseware and interactive teaching mode using panel presentations, role play, classroom discussions and other teaching methods, changing the classroom entirely controlled by teachers, students listen to talk about the shortcomings of notes, so that students become more involved in teaching activities, even control section selects teaching content and teaching progress, thus becoming one of the teaching body.

Third, the timely exchange more. Interactive multimedia technology in teaching business English, not only reflects the two-way interaction between teachers and students, but also to achieve human-computer interaction, and thus more conducive to feedback timely and accurate.

Fourth, application is practical theory. In the traditional teaching methods, mostly for teachers to make a few specific examples to illustrate how various business activities in the English language application, which shows business activities from real life and the use of multimedia technology, interactive immersive Teaching role-playing and group discussions and exchange, to realize the practical effect of teaching theory far.

\section{References}

1. Ding Jian Ge multimedia material acquisition and production of Beijing Higher Education Press, 23(2000)

2. Wang Yue Design and Research of interactive multimedia courseware, Tsinghua University master's thesis 34(1999)

3. Wang Wei "Direetor7.0 application and production instances" Science Press, 123,(2008)
4. Qing Han computer studio "Director7.0 multimedia production examples of" Machinery Industry Press, 120(2000)

5. Zhang Xian sound technical and artistic resolve singing. People's Music, 154(2005)

6. Cuiquan Xin Singing resonance cavity resonance and three practical exercises. Xinghai Conservatory of Music School Newspaper, 25(2001)

7. Xia Xianping vocal cords, glottis and vocal. Biology Bulletin, 198(2012)

8. Zhu Jiming, Rick Chan, Lubbe real larynx anatomical study. Shanxi: Anatomy, 213(2009) 